\title{
GENDER DIVERSITY DAN GOOD CORPORATE GOVERNANCE TERHADAP FINANCIAL DISTRESS \\ Oleh:
}

Guruh Dwi Samudra

Fakultas Ekonomi dan Bisnis, Universitas Airlangga, Surabaya

Email: guruh.dwi.samu-2019@feb.unair.ac.id

\begin{tabular}{l}
\hline Article Info \\
\hline Article History : \\
Received 29 July - 2021 \\
Accepted 02 Sept - 2021 \\
Available Online 25 Sept - \\
2021
\end{tabular}

Keyword:

board of commissioners,

financial distress, gender

diversity, good corporate

governance, , independent

board, and institutional

ownership

\section{PENDAHULUAN}

Financial distress merupakan keadaan perusahaan yang sedang mengalami kesulitan atau penurunan kinerja pada bagian keuangan yang terjadi secara berkelanjutan selama beberapa periode yang dapat berujung pada kebangkrutan (Platt \& Platt, 2002). Kondisi kesulitan keuangan perusahaan dapat bermula dari kesulitan likuiditas jangka pendek hingga kebangkrutan sebaga tingat kesulitan keuangan yang paling tinggi (Triwahyuningtias, 2012). Dapat disimpulkan bahwa financial distress adalah kondisi keuangan perusahaan yang semakin memburuk selama beberapa periode dan dapat berujung pada kebangkrutan jika kondisi buruk tidak segera diatasi.

AFTA (Asean Free Trade Area) atau yang lebih dikenal dengan perdagangan bebas yang diberlakukan sejak tahun 2020 dan kemudian akan diberlakukan secara utuh pada tahun 2015 dianggap dapat merubah bentuk perdagangan serta persaingan yang ada di Indonesia sebagai anggota dari ASEAN. Perusahaan yang masih belum memiliki kemampuan dalam mengelola perusahaan maupun kemampuan bersaing yang baik tentu akan kesulitan dalam menghadapi adanya kebijakan baru yang akan diterapkan karena dapat meningkatkan persaingan yang ada. Perusahaan yang tidak mampu bersaing dapat mengalami kesulitan dalam menjalankan 
perusahaannya dan dapat berujung pada kesulitan pada kondisi keuangan perusahaan. Apabila kondisi kesulitas keuangan tidak segera ditangani maka perusahaan dapat berpotensi mengalami kondisi financial distress.

Masalah Keagenan atau agency problem dianggap dapat menjadi salah satu penyebab financial distress pada suatu perusahaan. Hal tersebut dikarenakan adanya perbedaan kepentingan antara pihak manajemen perusahaan dengan pemilik perusahaan yang sering menyebabkan adanya perbedaan pendapat dalam menentukan keputusan yang jika tidak dikelola dengan baik dapat berpotensi merugikan perusahaan. Menurut Bodroastuti (2009) agency conflict dipengaruhi oleh struktur kepemilikan dalam suatu perusahaan. Dengan adanya permasalahan yang dapat timbul tersebut maka perusahaan sebaiknya memiliki suatu pengendalian yang dapat menyeimbangkan kepentingan antara manajemen perusahaan dengan pemegang kepentingan sehingga biaya yang timbul dari masalah agensi dapat dikurangi.

Corporate Governance atau dikenal dengan tata Kelola perusahaan merupakan perangkat aturan dalam mengatur dan mengendalikan hubungan antara pihak manajemen, pemegang saham, kreditor, karyawan, pemerintah dan pihakpihak yang berkepentingan lainnya (FCGI, 2001). Dalam kata lain tata Kelola perusahaan adalah suatu sistem yang dapat mengendalikan serta mengarahkan perusahaan. Mekanisme yang terdapat di corporate governance bertujuan untuk meningkatkan nilai pada semua pihak yang berkepentingan sehingga konflik agensi antara pemilik perusahaan dengan manajemen dapat terhindarkan (Bodroastuti, 2009). Dengan adanya sistem tata Kelola perusahaan yang baik yang berguna dalam mengawasi kinerja perusahaan maka diharapkan kondisi financial distress dapat dihindari.

Penerapan corporate governance terdapat elemen-elemen pembentuk didalamnya. Elemen pembentuk dalam corporate governance diantaranya kepemilikan institusional, dewan komisaris, kepemilikan manajerial, komite audit, komposusu dewan komisaris independen (Fathonah, 2016). Mengingat Indonesia merupakan negara berkembang serta memiliki kemampuan keuangan yang kurang baik yang terbukti dengan semakin rendahnya nilai tukar rupiah terhadap niai Dollar AS pada awal tahun 2016 yang mencapai Rp13.200 - per dollar AS, maka penelitian ini dilakukan agar Indonesia dapat mengantisipasi berbagai resiko dan solusi agar tidak mengalami kesulitan keuangan atau financial distress.

Ayuningtyas (2013) melakukan penelitian mengenai corporate governance dengan menggunakan elemen jumlah dewan komisaris sebagai variabel penelitian menunjukkan adanya pengaruh negatif terhadap financial distress. Hasil tersebut mengidnikasikan bahwa tingkat pengawasan terhadap manajemen perusahaan yang baik akan meningkatkan kinerja perusahaan. Sementara itu penelitian yang dilakukan oleh Bodroastuti (2009) memberikan hasil yang berbeda dengan peneliti sebelumnya yang menunjukkan bahwa terdapat pengaruh positif dewan komisaris terhadap financial distress. Hasil tersebut menunjukkan perusahaan yang memiliki jumlah dewan komisaris yang besar akan memberikan kinerja pengawasan yang relative lemah. Hasil yang berbeda juga ditunjukkan oleh penelitian Deviacita \& Achmad (2012) yang menunjukkan hasil bahwa jumlah dewan komisaris tidak memiliki pengaruh terhadap financial distress.

Elemen kepemilikan institusional pada corporate governace juga menunjukkan hasil yang berbeda pada bebrerapa penelitian yang telah dilakukan dalam pengaruhnya terhadap financial distress. Penelitian oleh Deviacita \& Achmad (2012) memberikan hasil kepemilikan institusional berpengaruh negatif terhadap financial distress. hasil berbeda disajikan oleh penelitian Bodroastuti (2009) dan Fathonah (2016) membuktikan bahwa tidak ada pengaruh antara kepemilikan institusional dengan financial distress. Deviacita \& Achmad (2012) menunjukkan hasil bahwa komisaris independen tidak berpengaruh terhadap financial distress sedangkan penelitian oleh Fathonah (2016) menunjukkan bahwa dewan komisaris independen berpengaruh negatif terhadap financial distress.

Kristanti, dkk. (2016) menguji pengaruh gender diversity dalam penelitiannya terhadap financial distress. Penelitian tersebut menunjukkan bahwa keberagaman gender atau gender diversity memiliki pengaruh negatif terhadap financial distress. Hasih tersebut menujkkan bahwa Wanita memiliki sikap hati-hati serta cenderung menghindari resiko. Sikap tersebut dapat memberikan keamanan serta terhindar dari resiko yang dapat mengancam 
kondisi perusahaan sehingga dapat terhindar dari financial distress. Carter, dkk. (2007) dan Smith, dkk. (2006) dalam penelitiannya juga memberikan hasil serupa bahwa gender diversity berpengaruh positif terhadap kinerja perusahaan yang berarti resiko atas financial distress juga akan semakin berkurang. Penelitian mengenai keberagaman gender di Indonesia masih sedikit dilakukan sehingga membuat peneliti terdorong untuk melakukan penelitian mengenai hal tersebut.

Dengan adanya penelitian yang sudah dilakukan oleh peneliti terdahulu mengenai gender diversity dan corporate governance terhadap financial distress namun memiliki gap atau hasil yang berbeda-beda. Jenis perusahaan dan tahun penelitian juga menjadi penyebab adanya hasil yang berbeda-beda sehingga penelitian akan dianggap lebih relevan ketika dilakukan pada jenis perusahaan serta tahun yang sesuai dengan kebutuhan pengguna hasil penelitian. Dengan demikian maka peneliti ingin menguji kembali bagaiamana pengaruh dari gender diversity dan corporate governance yang diukur dengan elemen dewan komisaris, kepemilikan institusional, dewan komisaris independen terhadap financial distress. Pada penelitian ini objek yang akan digunakan adalah perusahaan manufaktur yang terdafar di Bursa efek Indonesia tahun 2014-2016.

Dari Uraian latar belakang yang ada maka beberapa masalah yang akan dibahas dalam pennelitian ini adalah apakah gender diversity, dewan komisaris, dewan komisaris independen, dan kepemilikan institusional berpengaruh terhadap financial distress?

\section{KAJIAN PUSTAKA DAN PENGEMBANGAN HIPOTESIS Teori Keagenan}

Masalah keagenan atau dikenal dengan agency conflict merupakan permasalahan yang timbul atas adanya pihak agent dan principle. Jensen \& Meckling (1976) menyatakan dimana satu orang yang disebut sebagai principle mempekerjakan orang lainnya yang disebut agent dalam menjalankan suatu perusahaan. Adanya konflik antara pengurus perusahaan dengan pemilik perusahaan dapat berpotensi munculnya ketidakseimbangan informasi yang dimiliki pengurus perusahaan dengan pemilik perusahaan untuk kepentingan pribadi sehingga pengurus cenderung akan memberikan informasi yang tidak lengkap kepada pemilk perusahaan (Pamudji \& Trihartati, 2010).

\section{Gender diversity}

Gender Diversity atau keberagaman gender dalam sebuah perusahaan diharapkan dapat memberikan hal positif bagi perusahaan dalam hal inovasi, kreatifitas, serta pandangan yang berbeda (Robinson \& Dechant, 1997). Hadirnya Wanita dalam jajaran direksi jga dipercaya dapat menghindarkan perusahaan dari resiko yang dihadapi karena Wanita akan cenderung lebih berhati-hati dan menghindari resiko jika dibanding dengan pria (Kristanti, dkk., 2016). Proporsi yang tepat antara pria dan Wanita diharapkan dapat menciptakan sinergi yang baik sehingga tercapai keseimbangan dalam proses pengambilan keputusan perusahaan yang lebih baik. Carter, dkk. (2007) dan Smith, dkk. (2006) dalam penelitiannya juga menunjukkan bahwa gender diversity memiliki pengaruh positif terhadap kinerja perusahaan. Dengan semakin baiknya kinerja perusahaan maka diharapkan perusahaan akan terhindar dari kondisi financial distress. Dengan demikian maka penulis mengajukan hipotesis sebagai berikut:

H1 : Gender diversity berpengaruh negatif terhadap financial distress.

\section{Dewan Komisaris}

Dewan komisaris dalam perusahaan berfungsi sebagai pengawas dan pengendalian atas kinerja dewan direksi dalam menjalankan tugasnya sebagai penggerak perusahaan (Triwahyunigtyas, 2012). Dengan adanya pengawasan yang kuat atas segala keputusan dari dewan direksi maka diharapkan dapat mengurangi permasalan agensi karena setiap keputusan yang dibuat oleh direksi harus selalu mempertimbangkan kesejahteraan pemegang kepentingan. Dengan begitu maka direksi akan menjalankan perusahaan sesuai dengan keinginan pemilik perusahaan (Wardhani, 2007)

Penelitian oleh Wardhani (2007) dan Ayuningtias (2013) membuktikan dewan komisaris berpengaruh negatif terhadap financial distress. Hubungan tersebut terjadi karena semakin banyak dewan komisaris dalam perusahaan maka fungsi pengawasan akan semakin baik sehingga kinerja dari direksi akan semakin baik dan berujung pada peningkatan kinerja perusahaan yang dapat mengindarkan resiko perusahaan mengalami financial distress. Berdasarkan hal tersebut maka peneliti mengajukan hipotesis.

H2 : Dewan komisaris berpengaruh negatif terhadap financial distress. 


\section{Dewan Komisaris Independen}

Komisaris independen dalam perusahaan berfungsi sebagai pengawas kinerja perusahaan yang dianggap lebih kuat dibanding dengan dewan komisaris karena mampu memberikan pengawasan yang lebih independent sehingga manajemen perusahaan tidak bisa melakukan perbuatan yang dapat merugikan perusahaan (Ayuningtyas, 2013). Penelitian oleh Fathonah (2016) dan Kristanti, dkk (2016) menunjukkan hasil dewan komisaris independen berpengaruh negatif terhadap financial distress karena dewan komisaris independen adalah bagian penting dalam setiap proses pengambilan keputusan yang akan dilakuakn oleh direksi.

Dewan komisaris independen adalah pihak independen dari luar perusahaan yang kinerjanya tidak dipengaruhi oleh pihak internal perusahaan sehingga diharapkan pengawasan terhadap manajemen perusahaan akan lebih optimal dan mampu mengurangi resio terjadinya financial distress. Dengan demikian maka penulis mengajukan hipotesis sebagai berikut:

H3 : Komisaris independen berpengaruh negatif terhadap financial distress.

\section{Kepemilikan Institusional}

Fungsi pengawasan perusahaan yang lebih baik juga berasal dari bagian yang bukan merupakan bagian langsung dari perusahaan yaitu kepemilikan saham perusahaan oleh pihak institusi sepeti bank, perusahaan investasi, perusahaan asuransi serta kepemilikan institusi yang lainnya. Kepemilikan oleh institusi dianggap mampu meningkatkan fungsing pengawasan yang lebih baik karena pihak institusi adalah pihak eksternal perusahaan yang merupakan bagain dari pemegang kepentingan yang senantiasa mengharapkan kinerja yang baik oleh perusahaan.

Kepemilikan saham perusahaan oleh perusahaan institusional eksternal menghasilkan manajemen yang fokus pada kinerja perusahaan (Elloumi \& Gueyié, 2001). Kepemilikan Institusional yang besar juga menunjukkan kemampuan perusahaan institusi dalam mengawasi perusahaan. (Triwahyunigtyas, 2012).

Penelitian oleh Ayunigtyas (2013), Triwahyunigtyas (2012) dan Deviacita \& Achmad (2012) membutikan kepemilikan institusional berpengaruh negatif terhadap financial distress karena semakin tingginya kepemilikan institusional dalam suatu perusahaan, semakin baik pengawasan terhadap pihak manajemen perusahaan dalam proses pengambilan keputusan yang berujung pada peningkatan kinerja perusahaan. Dengan demikian penulis mengajukan hipotesis sebagai berikut:

H4 : Kepemilikan institusional berpengaruh negatif terhadap financial distress

\section{METODE PENELITIAN \\ Pendekatan Penelitian}

Pendekatan penelitian yang digunakan pada penelitian ini adalah pendekatan kuantitatif. Pendekatan tersebut digunakan karena penelitian ini fokus pada mengujian teori menggunakan variabel yang terukur dengan angka serta analisis yang digunakan yaitu prosedur statistik yang berguna untuk menjawab masalah yang telah dirumuskan sebelumnya. Selanjutnya riset korelatif digunakan dalam penelitian ini untuk menguji pengaruh variabel independen yang terdiri dari gender diversity, dewan komisaris, kepemilikan institusional dan dewan komisaris indepeden terhadap variabel dependen yaitu financial distress.

\section{Populasi dan Sampel}

Pupulasi yang digunakan pada penelitian ini yaitu perusahaan manufaktur yang terdaftar di Bursa Efek Indonesia pada tahun 2014-2016. Teknik pemilihan sampel dalam penelitian ini menggunakan teknik purposive sampling dimana sampel ditentukan oleh peneliti berdasarkan kriteria-kriteria yang sudah ditetapkan. Teknik purposive sampling digunakan agar data sampel yang diperoleh merupakan data yang sesuai serta dapat memberikan hasil yang optimal. Kriteria pemilihan sampel adalah sebagai berikut:

1. Perusahaan manufaktur yang terdaftar di BEI (Bursa Efek Indonesia) tahun 20142016.

2. Memiliki data yang lengkap serta informasi yang dibutuhkan dalam melakukan penelitian

\section{Sumber dan metode pengumpulan data}

Data yang digunakan penelitian ini adalah data sekunder yang diperoleh dari laporan keuangan serta laporan tahunan perusahaan yang ada di publikasikan oleh BEI (Bursa Efek Indonesia) tahun 2014-2016. Laporan keuangan dan tahunan perusahaan diperoleh dari Bursa Efek Indonesia yang dapat diakses dari website resmi Bursa Efek Indonesia www.idx.co.id. Metode pengumpulan data dilakukan dengan cara mengumpulkan 
seluruh laporan keuangan dan laporan tahunan perusahaan yang selama tahun 2014-2016 kemudian dipilih berdasarkan kriteria pemilihan sampel yang telah ditetapkan. Kemudian langkah selanjutnya adalah mengambil data-data yang dibutuhkan dalam laporan keuangan yang berhubungan dengan variabel dalam penelitian. Setelah terkumpul semua data yang dibutuhkan maka selanjutnya data akan dianalisis.

\section{Definisi Operasional \\ Financial distress}

Pengukuran variabel financial distress pada penelitian ini mengacu pada penelitian sebelumnya yang dilakukan oleh Xiao, dkk (2012) yang menganggap perusahaan mengalami financial distress apabila suatu perusahaan mengalami kerugian atau laba bersih negatif selama 2 tahun berturut-turu. Informasi kerugian perusahaan dapat dilihat dari bagian laba/rugi perusahaan yang ada pada laporan keuangan tahunan perusahaan dan membandingkan dengan tahun sebelumnya. variabel financial distress pada penelitian ini merupakan variabel dummy yaitu akan diberi nilai 1 jika perusahaan mengalami financial distress dan nilai 0 apabila perusahaan tidak sedang mengalami financial distress.

\section{Gender diversity}

Variabel gender diversity pada penelitian ini diukur dengan membandingkan jumlah direksi berjenis kelamin Wanita dengan jumlah total direksi yang ada dalam sebuah perusahaan. Berikut rumus pengukuran:

Gender diversity : X / Y

Keterangan :

$\mathrm{X}=$ wanita dalam jajaran direksi

$\mathrm{Y}=$ total jumlah direktur

\section{Dewan komisaris}

Dewan komisaris diukur dengan menghitung berapa banyak jumlah dewan komisaris pada suatu periode yang ada pada sebuah perusahaan (Wardhani, 2007). Data jumlah dewan komisaris dapat diperoleh dari laporan keuangan tahunan perusahaan

\section{Dewan Komisaris Independen}

Viariabel dewan komisaris independen diukur dengan membandingkan jumalh dewan komisaris independent dengan jumlah total dewan komisaris yang ada pada suatu perusahaan pada suatu periode (Wardhani, 2007). Berikut rumus pengukuran dewan komisaris independent:

Proporsi dewan komiaris independen $=\mathrm{X} / \mathrm{Y}$

Keterangan :
$\mathrm{X}=$ Jumlah dewan komisaris independen dalam perusahaan pada periode $t$

$\mathrm{Y}=$ jumlah total dewan komisaris pada sebuah perusahaan pada periode $\mathrm{t}$

\section{Kepemilikan Institusional}

Dalam penelitian ini variabel kepemilikan institusional diukur dengan membandingkan jumlah saham yang dimiliki oleh pihak institusi dengan jumlah total saham yang ada. Pengukuran tersebut mengacu pada penelitian yang dilakukan oleh Wardhani (2007). Berikut rumus pengukuran kepemilikan institusional:

Proporsi kepemilikan institusional : X / Y

Keterangan :

$\mathrm{X}=$ saham intstitusional

$\mathrm{Y}=$ total saham yang beredar

\section{Teknik Analisa Data}

Teknik analisis data yang digunakan penelitian ini menggunakan statistik deskriptif yang bertujuan untuk mengetahui gambaran data yang telah diperoleh. Kemudian data yang telah diperoleh akan dianalis dengan menggunakan regresi logistik untuk mengetahui hubungan antar variabel yaitu variabel gender diversity, dewan komisaris, dewan komisaris independent, kepemilikan institusional terhadap varaibel financial distress. Alasan peneliti menggunakan Teknik analisis regresi logistik pada penelitian ini adalah karena variabel dependen merupakan variabel dummy.

\section{HASIL DAN PEMBAHASAN Analisis Deskriptif}

\section{Tabel 1}

Hasil Uji Deskriptif

\begin{tabular}{|c|c|c|c|c|c|}
\hline & $\mathrm{N}$ & Minimum & Maximum & Mean & Std. Deviation \\
\hline Gender & 380 & 0,00 & 0,66 & 0,09 & 0,149 \\
\hline Kom & 380 & 2 & 13 & 4,24 & 1,859 \\
\hline Indkom & 380 & 0,00 & 1,00 & 0,36 & 0,161 \\
\hline Inst & 380 & 0,00 & 0,99 & 0,68 & 0,225 \\
\hline
\end{tabular}

\section{Sumber : Hasil Olahan Data SPSS}

Berdasarkan observasi data yang telah diperoleh, total perusahaan manufaktur yang terdaftar pada tahun 2014 hingga 2016 sebanyak 389 perusahaan, namun berdasarkan kriteria pemilihan sampel yang telah ditetapkan maka diperoleh sampel sebanyak 380 perusahaan. Berdasarkan tabel 1 dapat dilihat untuk variabel keberagaman gender, dewan komisaris independen dan kepemilikan institusional memiliki nilai minimum 0 yang mengindikasikan bahwa di Indonesia masih ada perusahaan yang belum memperhatikan hal tersebut. Namun untuk variabel dewan komisaris semua perusahaan telah menerapkannya sehingga setiap perusahaan 
memilki dewan yang bertugas dalam mengawasi kinerja manajemen. Meski demikian jika dilihat dari nilai maksimal dari masing-masing-masing variabel maka di Indonesia juga terdapat perusahaan yang memilki kesadaran terhadap mekanisme good corporate governance serta keberagaman gender yang baik.

\section{Uji Kesesuaian Model}

Tabel 2

Hosmer and Lomeshow Test

\begin{tabular}{|c|c|c|}
\hline Chi-square & df & Sig. \\
\hline 10,825 & 8 & 0,212 \\
\hline
\end{tabular}

Sumber : Hasil Olahan Data SPSS

Tabel 2 menunjukkan nilai dari signifikansi sebesar 0,212 yang lebih besar dari 0,05 sehingga dapat disimpulakan model yang digunakan adalah fit dan dapat diterima.

\section{Koefisien Determinasi}

Tabel 3

Koefisien Determinasi

\begin{tabular}{|c|c|}
\hline Step & Nagelkerke R Square \\
\hline 1 & 0,043 \\
\hline
\end{tabular}

Sumber : Hasil Olahan Data SPSS

Dari Tabel 3 menunjukkan nilai dari Nagelkerke R Square sebesar 0,043. Dengan demikian maka variabel independen dalam penelitian ini mampu menjelaskan 4,3\% dalam memprediksi variabel dependen sedangkan sisanya dapat dijelaskan dengan variabel selain yang diteliti.

Uji Klasifikasi Model

Tabel 4

Classification Model

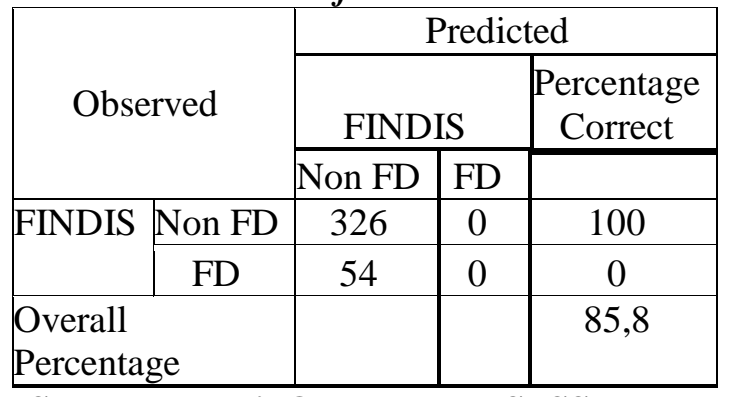

\section{Sumber : Hasil Olahan Data SPSS}

Berdasarkan tabel 4 menunjukkan kemapuan analisis regresi logistik dalam menjawab hipotesis adalah $85,8 \%$.

\section{Pengujian Hipotesis}

Tabel 5

Nilai Koefisien Regresi Logistik

\begin{tabular}{|l|c|c|c|c|l|}
\hline Variabel & B & S.E. & sig & Exp (B) & Keterangan \\
\hline Gender & $-2,085$ & 1,193 & 0,081 & 0,124 & H1 diterima \\
Kom & $-0,150$ & 0,090 & 0,097 & 0,861 & H2 diterima \\
Indkom & $-0,160$ & 0,880 & 0,856 & 0,852 & H3 ditolak \\
Inst & 1,294 & 0,750 & 0,085 & 3,646 & H4 ditolak \\
Constant & $-1,874$ & 0,743 & 0,012 & 0,153 & \\
\hline
\end{tabular}

Sumber : Hasil Olahan Data SPSS

Berdasarkan tabel 5 hasil pengujian dengan menggunakan nilai signifikansi $10 \%$ atau 0,1 dapat dianalisis sebagai berikut :

1. Nilai koefisien bertanda negatif $-2,085$ dengan tingkat signifikansi variabel gender diversity $0,081(\mathrm{p} \leq 0,1)$ sehingga disimpulkan ada pengaruh negatif yang signifikan antara gender diversity terhadap financial distress yang berarti hipotesis 1 dapat diterima

2. Nilai koefisien bertanda negatif sebesar 0,150 dengan tingkat signifikansi variabel jumlah dewan komisaris adalah $0,097$ ( $\mathrm{p} \leq 0,1)$ maka ada pengaruh negatif yang signifikan antara jumlah dewan komisaris terhadap financial distress sehingga dapat disimpulkan bahwa hipotesis 2 dapat diterima.

3. Nilai koefisien bertanda negatif sebesar 0,160 dengan tingkat signifikansi variabel dewan komisaris independen adalah $0,856(\mathrm{p}>0,1)$ maka ada pengaruh negatif yang tidak signifikan dewan komisaris independen terhadap financial distress sehingga dapat disimpulkan hipotesis 3 tidak dapat diterima.

4. Nilai koefisien bertanda positif sebesar 1,294 dengan tingkat signifikansi variabel jumlah dewan komisaris adalah $0,085(\mathrm{p} \leq 0,1)$ maka ada pengaruh positif yang signifikan antara kepemilikan institusional terhadap financial distress sehingga bahwa hipotesis 4 tidak dapat diterima.

\section{Pembahasan \\ Pengaruh Gender Diversity Terhadap Financial Distress}

Berdasarkan analisis yang telah dilakukan diperoleh hasil adanya hubungan negatif antara gender diversity dengan financial distress. hubungan tersebut mengimplikasikan bahwa semakin tinggi keberagaman gender direksi 
dalam sebuah perusahaan maka semakin rendah kemungkinan perusahaan mengalami financial distress. hasil tersebut dapat dikaitkan dengan pernyataan bahwa Wanita memilki pola pikir yang berbeda dibanding dengan pria sehingga apabila digabungkan maka dapat memberikan sinergi yang lebih baik dalam proses pengambilan keputusan.

Hasil dari penelitian ini juga serupa dengan penelitian sebelumnya oleh Kristanti, dkk. (2016). Penelitian oleh smith, dkk (2006) dan Carter, dkk. (2007) juga menunjukkan haisl serupa yaitu gender diversity berpengaruh postif terhadap kinerja perusahaan yang dimana mampu mengurangi potensi terjadinya financial distress. pandangan Wanita dalam mengelola resiko dianggap lebih aman dan cenderung menghindari resiko jika dibanding dengan pria sehingga keputusan yang akan diambil akan selalu memperhatikan resiko yang akan dihadapi sehingga keputusan yang akan dihasilkan mampu mengurangi potensi terjadinya financial distress.

\section{Pengaruh Dewan Komisaris Terhadap Financial Distress}

Hasil dari penelitian ini sesuai dengan hipotesis yang diajukan bahwa dewan komisaris berpengaruh negatif terhadap financial distress. hasil tersebut menunjukkan bahwa semakin banyak jumlah dewan komisaris yang ada dalam perusahaan maka akan semakin kecil kemungkinan perusahaan mengalami financial distress. semakin banyak jumlah dewan komisaris berarti akan semakin banyak pihak yang mengawasi kinerja manajemen perusahaan dan sebaliknya jika perusahaan memiliki dewan komisris yang sedikit maka pengawasan akan cenderung lemah dan dapat berpotensi menyebabkan masalah keuangan dalam perusahaan (Wardhani, 2007)

Dalam teori agensi yang sebelumnya telah dibahas dapat diketahui bahwa antara pihak manjemen perusahaan dan pemilik perusahaan memiliki kepentingan yang berbeda sehingga dibutuhkan pihak yang mampu mengawasi kinerja serta segala proses pengambilan keputusan oleh manajemen sehingga selalu memperhatikan kepentingan dari pemilik perusahaan. Dengan demikian maka semakin besar pengawasan yang ada pada perusahaan maka dapat meningkatkan kinerja perusahaan yang berujung pada berkurangnya potensi perusahaan mengalami kondisi financial distress.

\section{Pengaruh Dewan Komisaris Independen Terhadap Financial distress}

Hasil dari penelitian ini tidak sesuai dengan hipotesis yang dijukan dimana dewan komisaris independen berpengaruh negatif terhadap financial distress. dengan begitu dapat dikatakan bahwa semakin besar atau kecilnya dewan komisaris independen dalam perusahaan tidak akan mempengaruhi terjadinya financial distress pada sebuah perusahaan. Hal tersebut dapat terjadi karena di Indonesia saat ini adanya dewan komisaris independen dalam perusahaan hanyalah sebagai syarat atau sebatas untuk memenuhi peraturam yang ada sehingga kinerja yang diberikan dengan adanya dewan komisaris independen masih belum optimal terutama untuk mencegah terjadinya financial distress (Wardhani, 2007).

Hasil dari penelitian ini serupa dengan hasil penelitian yang dilakukan oleh Deviacita \& Achmad (2012) dan Triwahyuningtyas (2012). Kinerja dewan komisaris independen yang kurang optimal dalam perusahaan akan menyebabkan lemahnya pengawasan terhadap kinerja dewan direksi. Kurang optimalnya kinerja dewan komisaris independen juga dapat dipengaruhi kurangnya sikap independen dari anggotanya dalam menjalankan tugas.

\section{Pengaruh Kepemilikan Institusional Terhadap Financial distress}

Hipotesis yang diajukan tiidak sesuai dengan hasil pada penelitian ini karena menunjukkan hubungan positif antara kepemilikan institusional dengan financial distress. sehingga dapat disimpulkan bahwa semakin besar kepemilikan saham oleh pihak institusi maka semakin besar potensi perusahaan mengalami financial distress. Hasil serupa ditunjukan oleh penelitian oleh Aprianingsih (2016) dan Gunarsih (2003) dalam Bodroastuti (2009).

Kepemilikan saham oleh pihak instiusi dalam sebuah perusahaan biasanya memilki jumlah yang besar sehingga dapat memunculkan tindakan yang dapat menguntungkan dirinya sendiri tanpa memperhatikan kepentingan pemegang saham minoritas serta kepentingan perusahaan (Aprianingsih, 2016). Apabila keadaan tersebut dibiarkan terus menerus maka dapat menimbulkan ketidakseimbangan dalam proses pengambilan keputusan sehingga dapat menganggu proses pengambilan keputusan. Kinerja perusahaan dapat menurun apabila proses pengambilan keputusan tidak dilakukan dengan 
baik dan tentu dapat berujung pada kondisi financial distress. hasil ini sesuai dengan teori agensi yang menyatakan bahwa terdapat perbedaan kepentingan antara pemilik perusahaan dengan manajemen perusahaan. Fungsi dari kepemilikan institusi yang diharapkan dapat meningkatkan pengawasan justru terbalik menjadi negatif karena pihak institusi mampu memberikan gangguan dalam proses pengambilan keputusan yang dapat menguntungkan dirinya sendiri.

\section{KESIMPULAN DAN SARAN Kesimpulan}

Berdasarkan penelitian yang telah dilakukan diperoleh hasil dimana gender diversity dan dewan komisaris berpengaruh negatif signifikan terhadap financial distress. hal tersebut dikarenakan Wanita memiliki sikap hati-hati dan cenderung menghindari resiko serat memiliki pola pikir yang berbeda dengan pria sehingga proses pengambilan keputusan lebih optimal dan terhindar dari resiko financial distress. fungsi dewan komisaris dalam mengawasi kinerja manajemen perusahaan juga dianggap optimal karena dapat menjalankan fungsi pengawasan yang baik sehingga mampu meningkatkan kinerja perusahaan sehingga financial distress dapat dihindari.

Penelitian ini juga menunjukkan tidak adanya hubungan antara dewan komisaris independent terhadap financial distress. hal tersebut dikarenakan pendirian dewan komisaris di Indonesia dianggap hanya sebagai syarat pemenuhan aturan yang ada sehingga fungsi pengawasan kurang optimal. Selain itu penelitian ini juga menunjukkan hasil bahwa kepemilikan institusional berpengaruh positif terhadap financial distress. hasil tersebut dapat terjadi karena kepemilikan oleh pihak institusi dalam sebuah perusahaan biasanya cenderung besar dan dianggap mampu mengarahkan perusahaan untuk menghasilkan keputusan yang dapat menguntungkan dirinya sendiri sehingga proses pengambilan keputusan akan menjadi tidak kondusif dan tidak optimal sehingga dapat menurunkan kinerja perusahaan dan tentunya jika dibiarkan terus menerus dapat menyebabkan financial distress.

\section{REFERENSI}

Aprianingsih, A. (2016). Pengaruh Penerapan Good Corporate Governance, Struktur Kepemilikan, Dan Ukuran Perusahaan Terhadap Kinerja Keuangan Perbankan. Journal Profita, (5), 1-16.

Ayuningtias. (2013). Analisis Pengaruh Struktur Kepemilikan, Board Composition, dan Agency Cost Terhadap Financial Distress. Jurnal Ilmu Manajemen, 1(1), 158-171.

Bodroastuti, T. R. I. (2009). Pengaruh Struktur Corporate Governance terhadap Financial Distress. Jurnal STIE Widya Manggala, (2000), 1-15.

Carter, D. A., Souza, F. D., Simkins, B. J., \& Simpson, W. G. (2007). The diversity of corporate board committees and financial performance. Oklahoma State University, Working Paper. https://doi.org/10.2139/ssrn.1106698

Deviacita, A. W., \& Achmad, T. (2012). Analisis Pengaruh Mekanisme Corporate Governance Terhadap financial distress. Diponegoro Journal Of Accounting, 1(1), 1-15.

Elloumi, F., \& Gueyié, J. (2001). Financial distress and corporate governance: an empirical analysis. Corporate Governance: The International Journal of Business in Society, 1(1), 15-23. https://doi.org/10.1108/14720700110389548

Fathonah, A. N. (2016). Pengaruh Penerapan Good Corporate Governance, 1(2), 133-150.

Forum for Corporate Governance in Indonesia (FCGI)."Peranan Dewan Komisaris dan Komite Audit dalam Pelaksanaan Corporate Governance (Tata Kelola Perusahaan)", FCGI, Jakarta, 2001

Triwahyuningtias, M., \& Muharam, H. (2012). Leverage Terhadap Terjadinya Kondisi Finacial Distress ( Studi Pada Perusahaan Manufaktur Yang Terdaftar Di Bursa Efek Indonesia Tahun 2008-2010 ), 1, 1-14.

Jensen, M. C., \& Meckling, W. H. (1976). Theory of the firm: Managerial behavior, agency costs and ownership structure. Journal of Financial Economics, 3(4), 305-360. https://doi.org/10.1016/0304405X(76)90026-X

Kristanti, F. T., Rahayu, S., \& Huda, A. N. (2016). The Determinant of Financial Distress on Indonesian Family Firm. Procedia - Social and Behavioral Sciences, 219, 440-447. 
https://doi.org/10.1016/j.sbspro.2016.05.018

Pamudji, S., \& Trihartati, A. (2010). Pengaruh Independensi dan Efektivitas Komite Audit Terhadap Manajemen Laba. Jurnal Dinamika Akuntansi, 2(1), 21-29. https://doi.org/10.1017/CBO9781107415324 .004

Platt, H. D., \& Platt, M. B. (2002). Predicting corporate financial distress: Reflections on choice-based sample bias. Journal of Economics and Finance, 26(2), 184-199. https://doi.org/10.1007/BF02755985

Robinson, G., \& Dechant, K. (1997). Building a business case for diversity. Academy of Management Perspectives, 11(3), 21-31. https://doi.org/10.5465/AME.1997.9709231 661

Smith, N., Smith, V., \& Verner, M. (2006). Do women in top management affect firm performance?A panel study of 2,500 Danish firms. International Journal of Productivity and Performance Management, 55(7), 569593.

https://doi.org/10.1108/17410400610702160

Wardhani, R. (2007). Mekanisme Corporate

Governance Dalam Perusahaan Yang Mengalami Permasalahan Keuangan. Jurnal Akuntansi Dan Keuangan Indonesia, 4(1), 95-114. https://doi.org/10.21002/jaki.2007.05

Xiao, Z., Yang, X., Pang, Y., \& Dang, X. (2012). The prediction for listed companies' financial distress by using multiple prediction methods with rough set and Dempster-Shafer evidence theory. Knowledge-Based Systems, 26, 196-206. https://doi.org/10.1016/j.knosys.2011.08.0 01 